\title{
ANALISIS PENANGGULANGAN DEMAM BERDARAH DENGUE (DBD) DI KABUPATEN SRAGEN
}

\author{
Fiqi Nurbaya $^{(1)}$, Julia Pertiwi $^{(2)}$ \\ Prodi Rekam Medis dan Informasi Kesehatan \\ Fakultas Kesehatan Masyarakat, Universitas Veteran Bangun Nusantara ${ }^{(1,2)}$ \\ Email: fiqinaya@gmail.com,pertiwijulia26@gmail.com
}

\begin{abstract}
ABSTRAK
Penyakit Demam Berdarah Dengue (DBD) dengue hemorrhagic fever adalah penyakit virus yang ditularkan oleh nyamuk sehingga berpotensi terjadi Kejadian Luar Biasa (KLB). Penanggulangan KLB DBD sudah diatur dalam Pedoman Penyelidikan dan Penanggulangan Kejadian Luar Biasa yang diterbitkan oleh Kementerian Kesehatan Republik Indonesia. Secara nasional, kasus DBD mengalami penurunan. Tahun 2017 dilaporkan 22.000 kasus, menurun pada tahun 2018 menjadi 11.000 kasus. Kasus DBD di Jawa Tengah sejak awal tahun 2019 hingga akhir Januari 2019 tercatat 1.204 kasus. Beberapa kabupaten di wilayah Jawa Tengah yang telah mengalami peningkatan kasus DBD adalah Kabupaten Sragen (200 kasus). Dinas Kesehatan Kabupaten (DKK) Sragen mencatat bahwa ratusan kasus DBD tersebut ditemukan di 19 kecamatan dengan 3 kecamatan yang menyumbang angka tertinggi adalah Gemolong 11 kasus, Sumberlawang 15 kasus dan Mondokan 21 kasus. Tujuan penelitian ini adalah menganalisa situasi penanggulangan DBD di Kabupaten Sragen menggunakan pendekatan GAP Analysis Critical Succes Factor (CSF) penelian ini merupakan penelitian Case study dengan menggunakan pendekatan kualitatif. Penelitian ini akan menggali kesenjangan antara pedoman dan realita pada penanggulangan DBD di Kabupaten Sragen. Penelitian dilakukan di lingkup Dinas Kesehatan Kabupaten Sragen di bagian P2PL. Jumlah kasus DBD di Kabupaten Sragen sejak tahun 2014 sampai Juni 2019 sebanyak 2.462 dengan kasus tertinggi tahun 2016 sebanyak 875. Komponen yang dilakukan dinas kesehatan kabupaten sragen untuk mengatasi KLB DBD adalah komponen input dan komponen proses dan komponen output.
\end{abstract}

Kata kunci : Kejadian Luar Biasa, Demam Berdarah Dengue

\begin{abstract}
Dengue Hemorrhagic Fever (DHF) dengue hemorrhagic fever is a viral disease that is transmitted by mosquitoes, so there is the potential for Extraordinary Events (KLB). The handling of DHF outbreaks has been regulated in the Guidelines for Investigation and Management of Extraordinary Events published by the Indonesian Ministry of Health. Nationally, dengue cases have decreased. In 2017 there were 22,000 cases reported, decreasing in 2018 to 11,000 cases. DHF cases in Central Java since the beginning of 2019 until the end of January 2019 recorded 1,204 cases. Some districts in Central Java that have experienced an increase in dengue cases are Sragen District (200 cases). Sragen District Health Office (DKK) noted that hundreds of DHF cases were found in 19 sub-districts with 3 sub-districts contributing the highest number to Gemolong 11 cases, Sumberlawang 15 cases and Mondokan 21 cases. The purpose of this study is to analyze the situation of DHF prevention in Sragen Regency using the GAP Analysis Critical Success Factor (CSF) approach. This research is a case study research using a qualitative approach. This research will explore the gap between guidelines and reality in the handling of DHF in Sragen District. The study was conducted in the scope of the Sragen Regency Health Office in the P2PL section. The number of dengue cases in Sragen District from 2014 to June 2019 was 2,462 with the highest cases in 2016 as many as 875 . Components performed by the Sragen District Health Office to deal with DHF outbreaks are input components and process components and output components.
\end{abstract}

Keywords: Extraordinary Events, Dengue Hemorrhagic Fever. 


\section{PENDAHULUAN}

Penyakit Demam Berdarah Dengue (DBD) adalah penyakit virus yang ditularkan oleh nyamuk sehingga berpotensi terjadi Kejadian Luar Biasa (KLB). Kriteria KLB DBD meliputi: (1) Jumlah kasus baru DBD dalam periode bulan tertentu menunjukkan kenaikan dua kali lipat atau lebih dibandingkan angka rata-rata per bulan dalam tahun sebelumnya; (2) Timbulnya kasus DBD pada suatu daerah yang sebelumnya belum pernah terjadi; (3) Angka kematian DBD dalam kurun waktu tertentu menunjukkan kenaikan $50 \%$ atau lebih dibandingkan dengan periode sebelumnya dalam kurun waktu yang sama. Penanggulangan KLB DBD sudah diatur dalam Pedoman Penyelidikan dan Penanggulangan Kejadian Luar Biasa yang diterbitkan oleh Kementerian Kesehatan Republik Indonesia (Kemenkes RI).

Secara nasional, kasus DBD mengalami penurunan. Tahun 2017 dilaporkan 22.000 kasus, menurun pada tahun 2018 menjadi 11.000 kasus. Namun, beberapa provinsi di Pulau Jawa cenderung masih tinggi kasusnya (mencapai 300 kasus per minggu) karena kepadatan penduduk yang tinggi. Kasus tertinggi di Provinsi Jawa Tengah terjadi pada tahun 2017 lalu yaitu 8.000 kasus.

Kasus DBD di Jawa Tengah sejak awal tahun 2019 hingga akhir Januari 2019 tercatat 1.204 kasus. Beberapa kabupaten di wilayah Jawa Tengah yang telah mengalami peningkatan kasus DBD adalah Kabupaten Sragen (200 kasus), Kabupaten Grobogan (150 kasus), Kabupaten Pati (87 kasus), Kabupaten Jepara (78 kasus), dan Kabupaten Blora (75 kasus). Data Dinas Kesehatan Kabupaten (DKK) Sragen mencatat bahwa ratusan kasus DBD tersebut ditemukan di 19 kecamatan dengan 3 kecamatan yang menyumbang angka tertinggi adalah Gemolong 11 kasus, Sumberlawang 15 kasus dan Mondokan 21 kasus. Temuan kasus DBD tersebut menunjukkan adanya peningkatan dibanding tahun sebelumnya. Sepanjang tahun 2018, ditemukan ada 345 kasus DBD dan kematian sebanyak tiga kasus. Sejak 14 Januari 2019, DKK Sragen telah mendirikan Posko Penanggulangan DBD. Melalui posko ini, DKK Sragen melakukan penggulangan DBD, mengidentifikasi sumber penularan dan menggalakkan upaya pencegahan.

\section{METODE}

\section{Jenis dan Desain Penelitian}

Penelitian ini merupakan penelitian Case Study, dengan menggunakan pendekatan kualitatif. Penelitian Case Study merupakan suatu penelitian tindakan yang melibatkan partisipan dalam menganalisis sebuah masalah dan mengetahui kebutuhan, serta menentukan alternatif pemecahan masalah (Creswell, 2012).

Analisis situasi penanggulangan DBD di Kabupaten Sragen akan dilakukan dengan model sequencial explanatory. Desain sequencial explanatory melibatkan prosedur pengumpulan data kuantitatif untuk mengeksplorasi penyakit DBD dan program penanggulangan DBD. Kemudian dilakukan pengumpulan data kualitatif untuk menjelaskan dan menginterpretasikan lebih lanjut temuan pada data kuantitatif.

Penelitian ini akan menggali kesenjangan antara pedoman dan realita pada penanggulangan DBD di Kabupaten Sragen, dengan melihat dari sisi penyelenggalaraan penyelidikan epidemiologi, penyelenggaraan surveilans ketat, upaya pengobatan dan upaya pencegahan. Dalam mengkaji perencanaan strategi dan kebijakan penanggulangan, diperlukan suatu pendekatan dengan kerangka kerja yang berisi metode dan teknik yang sistematis. Metode atau kerangka pikir yang digunakan peneliti dalam menganalisis kebijakan penanggulangan DBD, mengacu pada pendekatan Critical Sucsess Factor Analysis (CSF) dan Gap Analisys.

Populasi pada penelitian ini adaah seluruh petugas kesehatan di lingkup Dinas Kesehatan Kabupaten Sragen yang berhadapan langsung maupun tidak langsung dengan program penanggulangan DBD. Pemilihan subyek penelitian dilakukan dengan metode purposive sampling, yaitu pengambilan sampel penelitian berdasarkan pertimbangan kriteria informan yang di anggap berkaitan dengan penelitian. Diperoleh informan berjumlah 5 orang, yaitu Kepala Bidang P2PL, Kepala Bagian P2PL dan 3 orang pemegang program DBD. 


\section{Diagram Alir Penelitian}

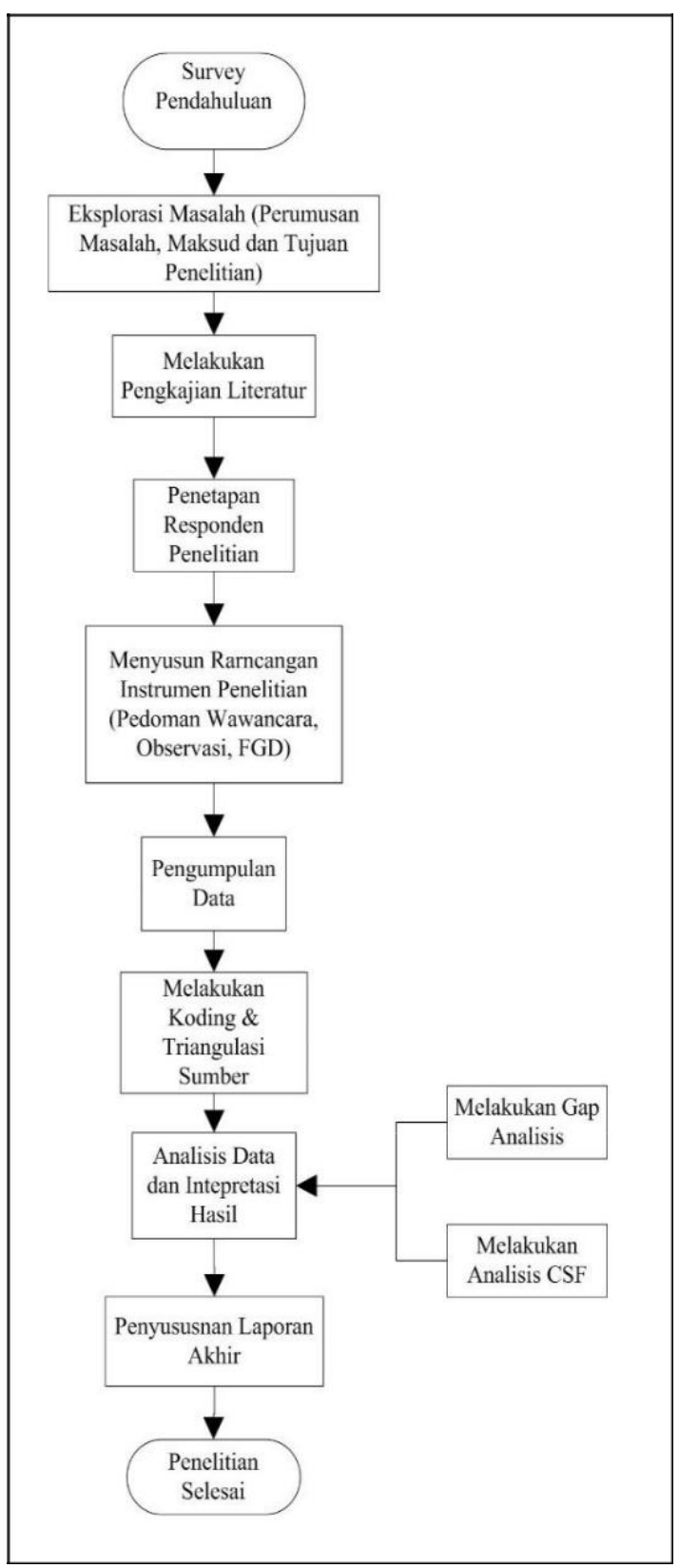

Gambar 1. Diagram Alir Penelitian

\section{Populasi dan Sampel}

Populasi pada penelitian ini adalah seluruh petugas kesehatan di lingkup Dinas Kesehatan Kabupaten Sragen yang berhadapan langsung maupun tidak langsung dengan program penanggulangan DBD. Pemilihan subyek penelitian dilakukan dengan metode purposive sampling, yaitu pengambilan sampel penelitian berdasarkan pertimbangan kriteria informan yang di anggap berkaitan dengan penelitian. Diperoleh informan berjumlah 5 orang, yaitu Kepala Bidang P2PL, Kepala Bagian P2PL dan 3 orang pemegang program DBD.

\section{Tehnik Pengumpulan Data}

Data dikumpulkan melalui observasi, telaah dokumentasi dan wawancara mendalam (indepth interview) kepada petugas terkait.

Indepth interview dilakukan terhadap keseluruhan responden dengan menanyakan pertanyaan yang sama. Langkah ini dilakukan untuk melakukan pengujian validitasdan reliabilitas data yang dihasilkan melalui triangulasi sumber.

\section{Instrumen Penelitian}

1. Pedoman Wawancara Mendalam

2. Pedoman Observasi

3. Pedoman Studi Dokumentasi

4. Lembar Kesediaan Responden (Informed Consent)

5. Alat tulis

6. Kamera

7. Recorder

\section{Prosedur dan Alur Penelitian}

1. Studi literatur: merupakan upaya untuk menjelajahi berbagai data dan informasi yang tertuang dalam buku, jurnal, laporan penelitian maupun informasi dari internet.

2. Observasi dan wawancara : merupakan upaya untuk penggalian data dan informasi mengenai penanggulangan DBD.

3. Telaah Dokumentasi : menggali informasi melalui dokumendokumen yang berkaitan dengan program penanggulangan DBD.

4. Analisis CSF : merupakan upaya melihat sisi kelemahan program dan kritisi kebijakan, serta faktor- faktor kunci keberhasilan program.

5. Gap Analisys : merupakan upaya untuk melihat sisi kesenjangan yang ada, antara realita dengan kebijakan/ aturan yang berlaku.

\section{Analisa Data}

1. Analisis isi (content analysis), yaitu melakukan analisis data 
kualitatif yang berasal dari hasil wawancara dan pengamatan langsung (observasi) dan data dipilih menurut relevansinya, serta disajikan dalam bentuk narasi.

2. Analisis sebab akibat (causalitas), yaitu melakukan analisis dari data yang diperoleh dan mencari hubungan atau penyebab dari masalah yang ada dengan faktorfaktor yang berkaitan.
3. Melakukan triangulasi data atau membandingkan hasil wawancara antar informan dengan pertanyaan yang sama dan juga membandingkan dengan hasil pengamatan yang telah dilakukan.

4. Melakukan koding, membuat transkrip,serta menginterpretasikan hasil wawancara.

\section{HASIL DAN PEMBAHASAN}

\section{Kasus Demam Berdarah Dengue (DBD) di Kabupaten Sragen}

Jumlah kasus DBD di Kabupaten

Sragen sejak tahun 2014 hingga Juni 2019 tercatat sebanyak 2.462 dengan kasus tertinggi pada tahun 2016 sebanyak 875 orang. Fluktuasi kasus DBD tahun 2014 - Juni 2019 disajikan pada Gambar berikut

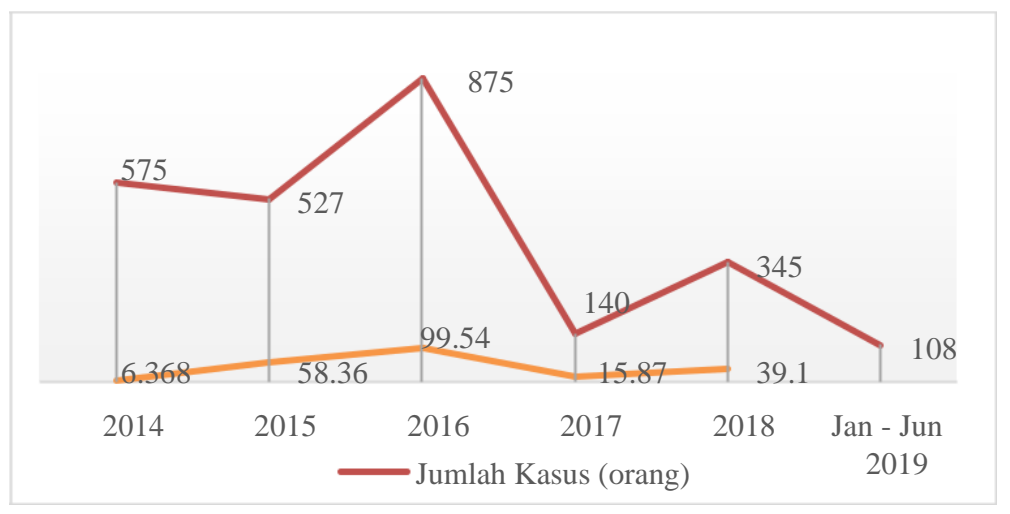

Gambar 2 Grafik Jumlah Kasus dan Incident Rate Kasus Demam Berdarah di Kabupaten Sragen Tahun 2014 - Juni 2019

Jumlah kematian akibat DBD tercatat 29 orang dengan kasus kematian tertinggi terjadi pada tahun 2014.

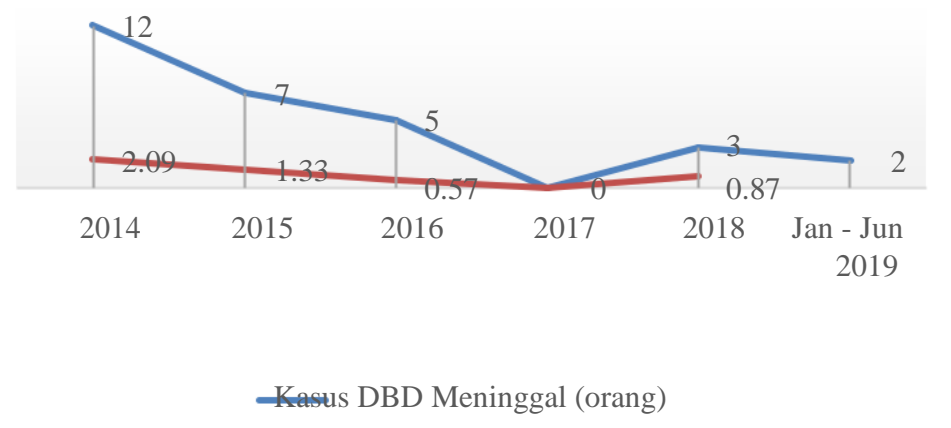

Gambar 3 Grafik Jumlah Kematian dan Case Fatality Rate Kasus Demam Berdarah di Kabupaten Sragen Tahun 2014 - Juni 2019 


\section{Distribusi Kasus DBD berdasarkan Orang} Berdasarkan grafik yang tersaji pada gambar 4 menunjukkan bahwa sebagian besar kasus DBD terjadi pada kelompok umur 15 44 tahun yakni sebesar $47 \%$. Kelompok umur ini merupakan usia produktif, baik dalam lingkup bekerja untuk mencari nafkah maupun kegiatan menuntut ilmu atau bersekolah. Kelompok ini juga merupakan kelompok dengan angka mobilisasi yang tinggi, sehingga tidak menutup kemungkinan bahwa kelompok umur ini terjangkit DBD di tempat kerja atau tempat bersekolah.

Distribusi kasus DBD di wilayah DKK Sragen berdasarkan jenis kelamin pada periode Januari - Juli 2019 menunjukkan bahwa kelompok laki-laki mencatatkan kasus

DBD lebih banyak dibandingkan perempuan (Gambar 5).

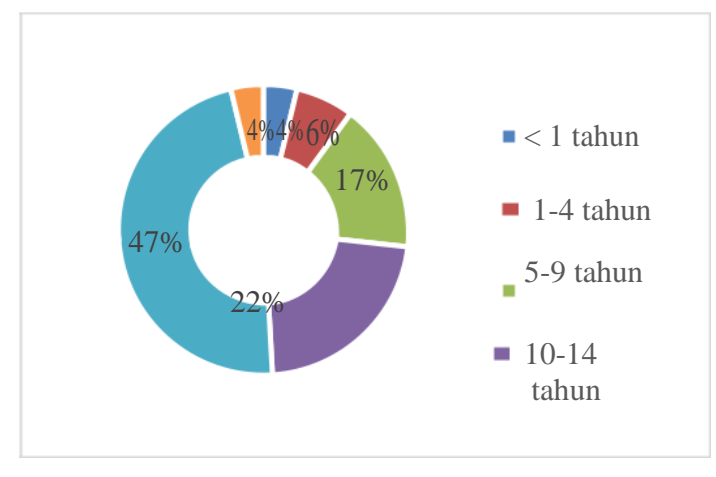

Gambar 4 Grafik Distribusi Penderita DBD berdasarkan Umur pada Januari - Juli 2019

Gambar 5 Grafik Distribusi Penderita DBD berdasarkan Jenis Kelamin pada Januari - Juli 2019

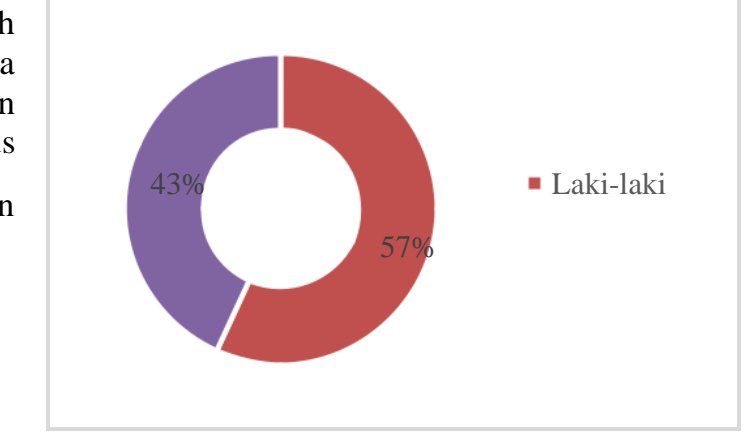

Distribusi Kasus DBD berdasarkan Tempat Berdasarkan data yang tersaji pada Gambar 6 diketahui bahwa wilayah dengan kasus DBD tertinggi meliputi wilayah Puskesmas: Mondokan, Sumberlawang, Gemolong, Sragen dengan masing-masing 10 kasus terkonfirmasi. Sedangkan, wilayah yang mencatatkan bebas dari DBD adalah Puskesmas Jenar. 
Total Kasus Terkonsirmasi DBD

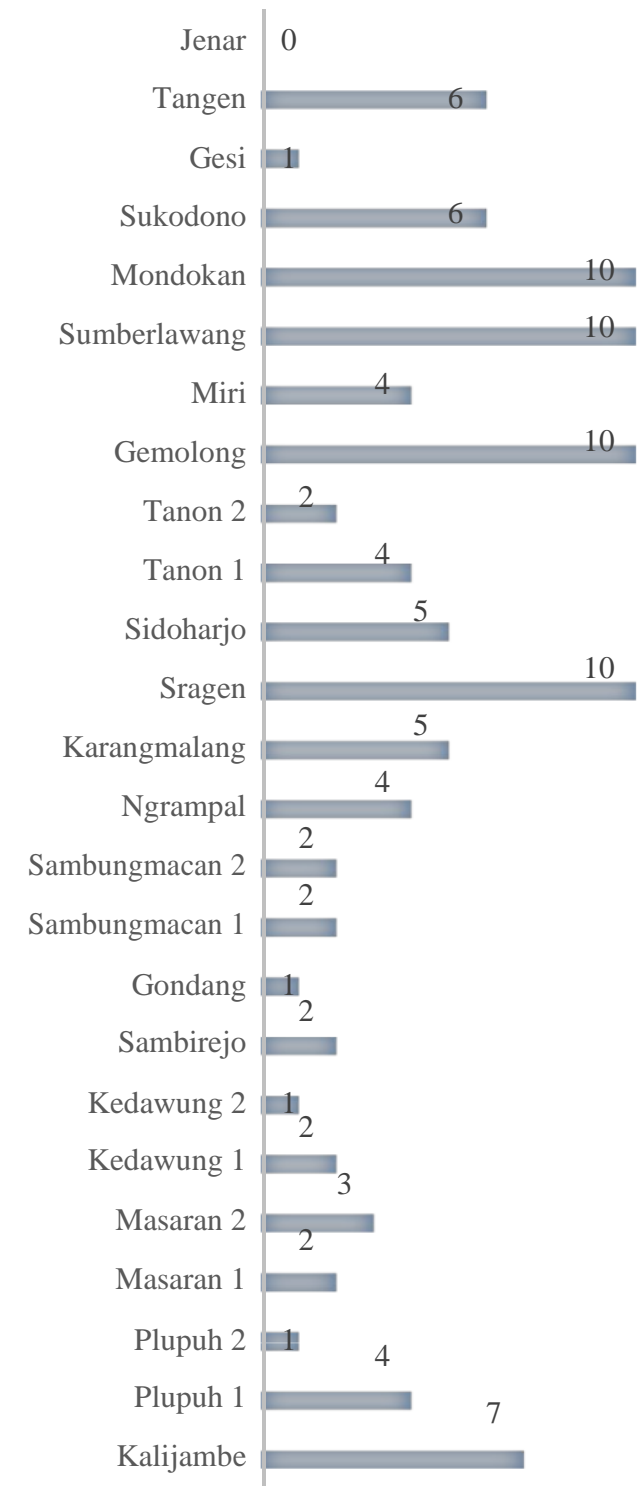

Gambar 6 Grafik Distribusi Penderita DBD berdasarkan Puskesmas pada Januari - Juli 2019

\section{Distribusi Kasus DBD berdasarkan Waktu}

Hasil penelitian menunjukkan tren cenderung positif, yang berarti terjadi penurunan kasus DBD yang signifikan.
Akan tetapi, data menunjukkan puncak kasus DBD terjadi pada Bulan Februari yang sekaligus merupakan puncak musim penghujan pada tahun 2019. Fluktuasi kasus DBD di wilayah DKK Sragen disajikan pada Gambar 7 


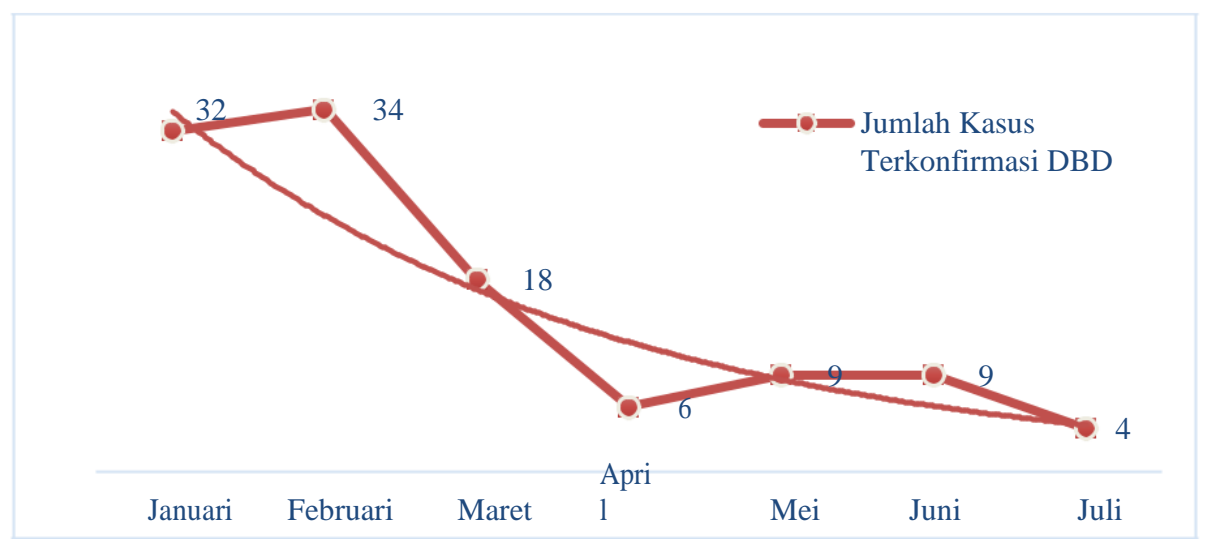

Gambar 7 Grafik Distribusi Penderita DBD berdasarkan Bulan pada Januari - Juli 2019

\section{Komponen Input dalam Penanggulangan DBD di Kabupaten Sragen}

1. Rapat koordinasi lintas program dan lintas sektor tingkat kabupaten pada tanggal 22 Januari 2019.

DKK Sragen dengan cepat tanggap segera melaporkan temuan kepada pemerintah. Selanjutnya, pemerintah Kabupaten Sragen segera melakukan rapat koordinasi lintas program dan lintas sektor.

2. Pembentukan posko DBD di tingkat Desa, Puskesmas / Kecamatan dan Kabupaten.

3. Setelah koordinasi yang dilakukan pada tanggal 22 Januari 2019, pemerintah secara serentak membentuk posko DBD baik di tingkat Desa, Puskesmas, Kecamatan dan Kabupaten. Posko ini bertugas untuk melakukan kewaspadaan dini dan sebagai rantai informasi.

4. Penerbitan Surat Edaran Bupati tentang pelaksanaan Pemberantasan Sarang Nyamuk (PSN) setiap hari Jumat.

5. Wujud komitmen nyata yang dilakukan pemerintah Kabupaten Sragen adalah dengan mencanangkan Gerakan PSN pada hari Jumat. Setiap hari Jumat, warga diwajibkan melakukan kegiatan yang dapat menurunkan kemungkinan nyamuk dapat berkembang biak. PSN dilakukan tidak hanya untuk memusnahkan dan menghindari gigitan nyamuk, namun juga memberantas tempat perindukan nyamuk.

6. Pembentukan kader siswa pemantau jentik (Simantik) di sekoah dari tingkat Sekolah Dasar (SD) sampai dengan Sekolah Tingkat Pertama (SMP)

7. Selain aktif di masyarakat, DKK Sragen juga menggandeng Dinas Pendidikan uuntuk membentuk Simantik di kalangan siswa SD dan SMP. Gerakan ini dilakukan pada sekolah yang berada di wilayah dengan kasus DBD yang tinggi.
8. Pembentukan kader gerakan satu rumah satu jumantik (G1R1J) pada tingakt dasa wisma Posyandu adalah unit kesehatan terkecil yang ada di masyarakat. Melalui pertemuan posyandu, ibuibu dibentuk menjadi G1R1J untuk menggalakkan PSN di lingkungan rumah mereka masingmasing.

9. Pembentukan kader juru pemantau jentik dari unsur saka bhakti husada

10. Saka Bhakti Husada yang berada di bawah Puskesmas,juga dilibatkan untuk melakukan PSN. Mereka menjadi pelaksana Pemantauan Jentik Rutin (PJR) di wilayahnya masing-masing.

11. Peningkatan kerjasama dengan PSC119 (patient Safety Centre) untuk informasi ketersediaan tempat tidur puskesmas, klinik dan rumah sakit

12. Meningkatnya jumlah kasus diduga DBD menimbulkan kepanikan tersendiri di masyarakat. Untuk mengatasi hal tersebut, agar seluruh masyarakat yang memiliki gejala DBD bisa segera mendapat pertolongan maka DKK Sragen melakukan kerjasama PSC119 untuk menyediakan informasi ketersediaan tempat tidur. Hal tersebut dilakukan, mengingat penyakit DBD yang tidak segera ditangani dapat berakibat fatal yaitu kematian.

\section{Komponen proses dalam penanggulangan DBD di Kabupaten Sragen}

1. Mengadakan penyuluhan untuk menekan pertambahan kasus dan mencegah terjadinya kasus

Penyuluhan dilakukan secara terus menerus di berbagai kelompok, antara lain: posyandu, Sekolah Dasar (SD) dan SMP dan ertemuan desa. Secara umum,penyuluhan menyasar kelompok unit terkecil (keluarga) agar PSN dapat berjalan semaksimal mungkin

2. Melakukan penyelidikan epidemiologi, apabila ada laporan kasus baik tertulis maupun telepon 
Seluruh kasus DBD (100\%) telah dilakukan Penyelidikan Epidemiologi (PE). Meskipun hasil print out tidak secara langsung (on time) diserahkan kepada pihak DKK, namun laporan hasil PE dan KDRS terus menerus dilakukan melalui group whats app.

3. Pelaksanaan Pemberantasan Sarang Nyamuk (PSN) secara serentak di setiap Desa, Kecamatan bersama seluruh elemen masyarakat, OPD dan Bupati.

PSN dilakukan setiap hari Jumat secara serentak dengan Bupati Sragen turut turun tangan melakukan program ini.

4. Pemberian larvasida /abate di tingkat dasa wisma.

5. Pemberian abate dilakukan melalui kegiatan Posyandu yang dilakukan di wilayah kasus DBD terjadi.

6. Dilaksanakan fogging focus apabila berdasarkan hasil penyelidikan epidemiologi memenuhi persyaratan.

7. Sebagian besar wilayah yang mencatatkan diri dengan kasus DBD tinggi bersedia melakukan fogging focus, namun sebenarnya masyarakat juga sudah mulai menyadari bahwa pengasapan bukanlah penyelesaian masalah dari DBD.

8. Penerapan aplikasi DBD Elektronik untuk verifikasi Kewaspadaan Dini Rumah Sakit (KDRS), guna menetapkan diagnosis.

9. Penggunaan aplikasi DBD Elektronik ini terbukti dapat mengkonfirmasi kasus DBD dengan lebih akurat. DKK Sragen baru menerapkan penggunaan DBD Elektronik pada tahun 2019 setelah terjadi dugaan terjadi KLB DBD

\section{Komponen Output Penanggulangan DBD}

1. KLB DBD ditangani kurang dari 24 jam.

Mengacu pada peraturan menteri keshatan

republik indonesia nomor 949/menkes/SK/VIII/2004 tentang pedoman penyelenggaraan sistem kewaspadaan dini kejadian luar biasa, Setiap daerah termasuk pemerintah Kabupaten Sragen menetapkan mekanisme agar setiap kejadian KLB dpat terdeteksi dini dan dilakukan tindakan penanggulangan dengan cepat dan tepat.

\section{SIMPULAN}

Ada 3 komponen yang dilakukan untuk mengatasi

kejadian luar biasa (KLB) DBD yaitu :

1. Komponen input berupa Rapat koordinasi lintas program dan lintas sektor tingkat kabupaten, Pembentukan posko DBD di tingkat Desa, Puskesmas / Kecamatan dan Kabupaten, Penerbitan Surat Edaran Bupati tentang pelaksanaan Pemberantasan Sarang Nyamuk (PSN) setiap hari Jumat, pembentukan kader siswa pemantau jentik (Simantik) di sekoah dari tingkat Sekolah
Dasar (SD) sampai dengan Sekolah Tingkat Pertama (SMP), pembentukan kader gerakan satu rumah satu jumantik (G1R1J) pada tingakt dasa wisma, pembentukan kader juru pemantau jentik dari unsur saka bhakti husada, . peningkatan kerjasama dengan PSC119 (patient Safety Centre) untuk informasi ketersediaan tempat tidur puskesmas, klinik dan rumah sakit

2. Komponen proses berupa Mengadakan penyuluhan untuk menekan pertambahan kasus dan mencegah terjadinya kasus, Melakukan

penyelidikan epidemiologi, Pelaksanaan Pemberantasan Sarang Nyamuk (PSN) secara serentak di setiap Desa, Kecamatan bersama seluruh elemen masyarakat, OPD dan Bupati, Pemberian larvasida /abate di tingkat dasa wisma. Dilaksanakan fogging focus apabila berdasarkan hasil penyelidikan epidemiologi memenuhi persyaratan, Penerapan aplikasi DBD Elektronik untuk verifikasi Kewaspadaan Dini Rumah Sakit (KDRS), guna menetapkan diagnosis

3. Komponen output berupa penanganan KLB DBD kurang dari 24 jam.

\section{DAFTAR PUSTAKA}

Altemimi, M.A.H., Zakaria, M.S. \& Mahmood, A.K., 2012. Assessing the Performance of Information Technology Strategic Planning for Organization Using Performance Measurement Framework. In International Conference on Computer \& Information Science (ICCIS). IEEE, pp. 164-169.

Bres, P., 1995. Tindakan Darurat Kesehatan Masyarakat Pada Kejadian Luar Biasa Petunjuk Praktis. Gajah Mada University Press, Cetakan pertama, Yogjakarta.

Chin, James, 2000. Control of Communicable Diseases Manual, American Public Health Association, 17th Editions, Washington .

Creswell, J.W., 2012. Educational Research Fourth Edi., Boston: PEARSON Publisher.

David, F., 2006. Manajemen Strategis: Konsep 10th ed., Jakarta: Salemba Empat.

Dirjen P2PL, 2011. Buku Pedoman Penyelidikan dan Penanggulangan Kejadian Luar Biasa Penyakit Menular dan Keracunan Pangan (Pedoman Epidemiologi Penyakit). Jakarta: Kemenkes RI.

DKK Sragen, 2019. Laporan Harian Posko Siaga DBD Kabupaten Sragen.

Infodatin, 2016. Situasi DBD. Pusat Data dn Informasi Kementerian Kesehatan Republik Indonesia.

Kaplan, R.S. \& David P, N., 1996. The Balanced Scorecard. 
Kemenkes RI, 2007. Modul Pelatihan Pencegahan dan Pemberantasan Demam Berdarah Dengue di Indonesia.

a, 2013. Pencegahan dan Penanggulangan Penyakit Demam Dengue dan Demam Berdarah Dengue. Departemen Kesehatan Republik Indonesia.

b, 2015. Pencegahan dan Pemberantasan Demam Berdarah Dengue di Indonesia. c, 2019. Laporan Situasi DBD.

LPPM Univet Bantara, 2018. Panduan Penelitian Kompetitif Bidang Ilmu (PKBI) Universitas Veteran Bangun Nusantara Tahun 2018 / 2019.
Nasir, S., 2005. The development change and transformation of management information system (MIS): A Content analysis of articles published in business and marketing journal. International journal of information management, 25, pp.442-457.

WHO, 2013. Global Incidence, Control Programme, Prevention Strategy for Dengue Hemoraghic Fever.

Yang, J., 2009. A Balanced Performance Measurement Scorecard Approach for Product Service Systems. In International Conference on Business Intelligence and Financial Engineering. Beijing: IEEE 